
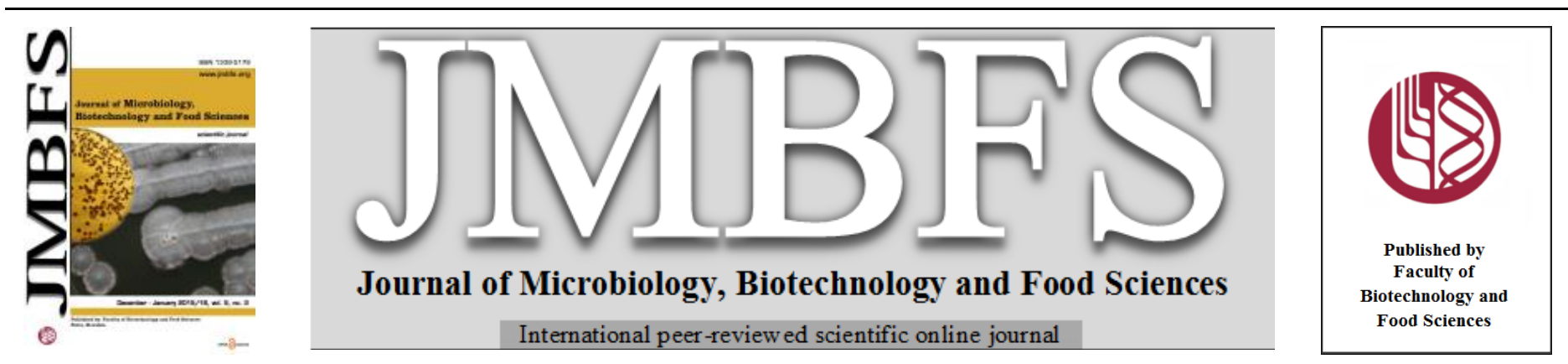

\title{
ISOLATION AND PRELIMINARY SCREENING OF ENDOPHYTIC FUNGI OF RICINUS COMMUNIS FOR THEIR ANTIMICROBIAL POTENTIAL
}

\author{
Pranay Jain* and Priyanka Sharma \\ Address(es): Dr. Pranay Jain, \\ ${ }^{1}$ Department of Biotechnology Engg., UIET, Kurukshetra University, Kurukshetra, Haryana, India-136119 Ph. +91-1744-239155.
}

*Corresponding author: drpranayjain@gmail.com

doi: $10.15414 / j m b f s .2015 / 16.5 .3 .230-233$

\section{ARTICLE INFO}

Received 30. 10. 2014

Revised 11. 6. 2015

Accepted 10. 9. 2015

Published 1. 12. 2015

Regular article open $\odot$ access

\begin{abstract}
The rapid increase in the antibiotic resistance among the microorganisms led to an everlasting need for new and improved antibiotics and nature serves as a vast source of antimicrobial agents. Present paper deals with the investigation of antimicrobial activity of endophytic fungal isolates obtained from the leaves, stem and beans of Ricinus communis plant against five Gram positive bacteria, two Gram negative bacteria and five fungal pathogens. Agar well diffusion method was used to evaluate the antimicrobial activity of these endophytic fungi. A total of thirty three fungal isolates were obtained from different samples and majority of the isolates (31 out of 33) showed the antimicrobial activity against at least one of the pathogenic microorganisms. Nineteen isolates were found to exhibit broad spectrum antimicrobial activity. The results revealed that $15 \%$ endophytic fungal isolates showed antimicrobial activity against Alternaria solani and Bacillus megaterim, 21\% against Bacillus subtilis and Candida glabrata, 33\% against Candida tropicalis and C. albicans,72\% against Escherichia coli, 3\% against Fusarium graminearum, 27\% against Pseudomonas fluorescens, Staphylococcus aureus and Streptococcus pyogenes and 15\% showed bioactivity against Streptococcus mutans. Thus, the results clearly indicate the potential of endophytic fungi isolated from Ricinus communis in the production of pharmaceutical drugs.
\end{abstract}

Keywords: Antimicrobial agents, Endophytic fungi, Pathogenic microorganisms, Bioactivity, Broad spectrum, Pharmaceutical drugs

\section{INTRODUCTION}

Nature has been exploited for the search of bioactive metabolites since ages. Ancient people depended greatly on the natural flora and fauna for their survival (Zahner et al., 1982). Natural product isolates (the term is usually reserved for secondary metabolites), i.e., the chemical compounds or substances derived from living organisms viz. plants, animals and microbial fermentation broths have been analyzed and evaluated for their beneficial effects. There are extensive records of use of natural products in ayurveda or traditional Chinese medicine system. Crude natural products, because of their low cost, have been directly used as drugs (Cutler et al., 2000; Bensky et al., 2004; Newman et al., 2007). Endophytes produce a wide range of compounds which are shown to combat pathogens and even cancers in animals including humans. (Singh et al., 2011). Endophytes are microorganisms that inhabit the inner tissues of the plant without causing any symptoms. Endophytic fungi are relatively unstudied group of microorganisms and hence, they offer a great opportunity for the isolation of a novel endophytic fungi or metabolite. They have been isolated from virtually all the plants that have been studied so far and hence, are regarded as a reservoir of potent bioactive metabolites (Strobel $\boldsymbol{e t}$ al., 2003). The endophytes isolated from the medicinal plants could serves as a promising source of antimicrobial agents (Radji et al., 2011).

Ricinus communis is a dicot plant belonging to the fourth largest family called 'Euphorbiaceae' family (spurge family). It is commonly known as castor. Castor is indigenous to India, southeastern Mediterranean Basin and Eastern Africa but is widespread throughout the world. Ricinus communis is a herbal medicine with great medicinal importance. All the parts of the plant (viz. leaf, bark, flower, seed, Oil etc.) have been reported to have medicinal value, and especially, the oil of this plant (called 'cathartic') has been extensively used in Ayurveda, Unani, Homeopathic and Allopathic system of medicines. Castor leaves are used in the treatment of rheumatism, headache, dropsy (edema), abscesses, ringworms, and warts. Also, they are used externally by nursing mothers to increase the flow of milk (Rana et al. 2012). Castor Oil is a natural emollient and can be applied to the skin and hair as a softener. Castor Oil is used to cure temporary constipation, colic and acute diarrhea, applied externally to treat ringworm and itch. Castor Oil can support labor and delivery (Azhari et al. 2006).
There are various studies on the antimicrobial potential of leaf extracts of Ricinus communis. A study evaluating the antibacterial, antifungal and the percentage inhibition of various extracts of leaf of Ricinus communis plant showed that the methanolic leaf extracts of the Ricinus communis has significant potential to inhibit both bacterial and fungal pathogens (Naz et al., 2012). Another study on the antimicrobial activity of various extracts of roots $(200 \mathrm{mg} / \mathrm{ml})$ of Ricinus communis established the potential of Ricinus communis as an effective antimicrobial agent against pathogenic microorganisms such as Escherichia coli, Staphylococcus aureus, Pseudomonas aeruginosa, Salmonella typhimurium, Proteus vulgaris, Bacillussubtilis, Candida albicans and Aspergillus niger (Mathur et al., 2011). A comparative study on the antibacterial effects of Ricinus communis leaf extract showed that leaf extracts have a better antibacterial activity in comparison with the standard drug named, gentamycin (Kota $\boldsymbol{e t}$ al., 2011).

In the present investigation, the endophytic fungi were isolated from the leaf, stem and beans of Ricinus communis plant to evaluate their antimicrobial activity against test pathogens.

\section{MATERIAL AND METHODS}

\section{Collection of plant sample}

Healthy and mature plant samples were randomly collected from differen locations of Kurukshetra, Haryana, India. Leaves, stem and castor bean specimen were excised with a sterile scalpel and labeled. The samples were brought to the laboratory in air tight zip lock bags and kept cold until processed.

\section{Surface sterilization of plant sample}

Sample was washed under running tap water and then with double distilled water. Sample was cut using sterile knife into small segments of $1.0 \times 1.0 \mathrm{~cm}$. The segments were immersed in 70\% ethanol for 1-3 minutes, followed by immersion in 4\% sodium hypochlorite for 5-7 minutes. The segments were rinsed with $70 \%$ ethanol and finally with sterilized double distilled water. The segments were then dried under aseptic conditions (Petrini et al., 1992). 


\section{Isolation of endophytic fung}

The surface sterilized sample was then placed on Potato Dextrose Agar plates and kept at $25-27^{\circ} \mathrm{C}$ for $5-7$ days in BOD incubator. The fungal isolates thus obtained were sub-cultured on Potato Dextrose Agar Slants and kept in the refrigerator at $4^{0} \mathrm{C}$ for further studies (Suryanarayanan, 1992)

\section{Obtainment of crude extracts}

The fungal crude extract was obtained by inoculating 2-3 disc of fungal isolate in a liquid medium, potato dextrose broth and incubating for 7-10 days at $25-27^{\circ} \mathrm{C}$ in a BOD incubator. After the incubation, the biomass was filtered (Whatman filter paper No. 1), and the cell-free filtrate was used in screening for antimicrobial activity (Tayung et al., 2010).

\section{Procurement and maintenance of test pathogens:}

The various pathogenic test microorganisms were procured from Microbial Type Culture Collection (MTCC), Institute of Microbial Technology (IMTECH), Chandigarh, which included Gram positive bacteria, Streptococcus mutans (MTCC 497), Staphylococcus aureus(MTCC 7443), Streptococcus pyogenes (MTCC 1924), B. megaterim (MTCC 428) and Bacillus subtilis (MTCC 121); Gram negative bacteria Escherichia coli (MTCC 40) and Pseudomonas fluorescens (MTCC 1748); fungal pathogens Candida albicans (MTCC 227), Candida glabrata (MTCC 3814) and Candida tropicalis (MTCC 3421). Two phytopathogenic fungi Alternaria solani (MTCC 10690) and Fusarium graminearum (MTCC 2089) were also obtained. The slants of brain heart infusion agar were made to preserve the cultures. All the slants were kept at $4{ }^{\circ} \mathrm{C}$ in the refrigerator for further studies.

\section{Screening for antimicrobial activity by agar well diffusion method}

The inoculum of different test pathogens was adjusted according to $0.5 \mathrm{Mc}$ Farland standards. A $200 \mu \mathrm{l}$ of test pathogen was spread aseptically using cotton Swabs on the surface of Mueller Hilton agar plates. Wells of about $6.0 \mathrm{~mm}$ diameter were aseptically punched in the agar plates using a sterile cock borer. A $100 \mu \mathrm{l}$ of the crude metabolite was transferred into each well. Plates were then kept in Laminar Air flow for 30 minutes for pre-diffusion of metabolite to occur and then incubated at $37^{\circ} \mathrm{C}$ for 24 hours. All the experiments were performed in triplicates and after 24 hours, the diameter of resulting zone of inhibition were measured in terms of millimeter (mm.) using a Hi-media zone scale (Corrado et al., 2004; Kumar et al., 2005).

\section{Identification of fungal isolates}

Fungal cultures were analyzed for spore structure, pigment formation and colony morphology and were identified up to generic level following volumes/monographs/manuals (Carol et al., 2009; Ellis 1971, 1976; Ainsworth et al., 1973; Barnett et al., 1998).

\section{Data analysis}

The relative frequency of colonization $(\% \mathrm{CF}$ ) was calculated as the number of segments colonized by a specific fungus divided by total number of segments plated X 100 and dominant endophytes were calculated as percentage colony frequency divided by sum of percentage of colony frequency of all endophytes $\mathrm{X}$ 100 (Tayung et al. 2010).

\section{RESULTS AND DISCUSSION}

In the present study, when the antimicrobial activity of endophytic crude extracts was compared with the standard commercial drug, ciprofloxacin; it was found that ciprofloxacin did not show any inhibition against Streptococcus pyogenes but the metabolites of the endophytic fungi isolated from leaves and stem showed an inhibitory zone ranging from $11 \mathrm{~mm}$. to $21 \mathrm{~mm}$. (in diameter). For other test bacterial pathogens, much wider zone of inhibition was viewed with ciprofloxacin as compared to the zone of inhibition displayed by endophytic fungal extracts.

The endophytes isolated from leaves, beans and even stem showed antifungal activity whereas the standard antifungal drug, fluconazol did not showed antimicrobial activity against any test fungal pathogens. An inhibitory zone ranging from $11 \mathrm{~mm}$. to $36 \mathrm{~mm}$. (in diameter) was observed when the crude extracts of endophytic fungi were used to check their antagonistic activity against test fungal pathogens (Table 1)

The evaluation of the antimicrobial and phytochemical properties of oil from Castor Seeds (Ricinus communis Linn) found that the minimum inhibitory concentration (MIC) of the extract ranged between 6.25 mg.ml-1 and 12.50 mg.ml-1 for bacteria while that of fungi ranged from $12.50 \mathrm{mg} . \mathrm{ml}-1$ to 25.00mg.ml-1, i. e, bacteria are more susceptible than fungi. Among the fungi, Fusarium oxysporum was the most sensitive while Aspergillus niger was least sensitive to the oil with zones of inhibition of $4.00 \mathrm{~mm}$ and $1.50 \mathrm{~mm}$ respectively (Momoh et al., 2012). This study also noted a similar trend, i.e., bacterial pathogens were found to be much more susceptible than fungal pathogens.

In the present study, a total of 33 endophytic fungi were isolated from leaf, bean and stem samples of Ricinus communis plant inhabiting different locations and 14 among them were found to be broad spectrum in their antimicrobial activity. Out of 33 endophytic fungal isolates obtained from Ricinus communis plant, 26 showed activity against one of the two gram-negative bacteria, 16 were antagonistic to atleast one of the five gram-positive bacteria, 17 showed antimicrobial activity against one of the three opportunistic fungal pathogens and 5 were antagonistic to one of the two phytopathogenic fungi. Table 1 shows the zone of inhibition displayed by various endophytic fungi against different pathogens.

Table 1 Antimicrobial activity of metabolites obtained from different fungal isolates

\begin{tabular}{|c|c|c|c|c|c|c|c|c|c|c|c|c|c|c|}
\hline \multirow{5}{*}{ Fungal Isolates } & \multirow{5}{*}{$\begin{array}{l}\text { SPECIES OF } \\
\text { ENDOPHYTIC } \\
\text { FUNGI }\end{array}$} & \multirow{5}{*}{ 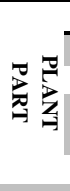 } & \multicolumn{12}{|c|}{ ZONE OF INHIBITION (IN MM.) } \\
\hline & & & \multirow{2}{*}{\multicolumn{7}{|c|}{$\begin{array}{l}\text { TEST PATHOGENS } \\
\text { BACTERIA }\end{array}$}} & \multirow{2}{*}{\multicolumn{5}{|c|}{ FUNGI }} \\
\hline & & & & & & & & & & & & & & \\
\hline & & & \multicolumn{5}{|c|}{ GRAM-POSITIVE } & \multicolumn{2}{|c|}{ GRAM-NEGATIVE } & \multicolumn{2}{|c|}{$\begin{array}{l}\text { OPPORTUNISTIC } \\
\text { PATHOGENS }\end{array}$} & \multicolumn{3}{|c|}{$\begin{array}{l}\text { PLANT } \\
\text { PATHOGENS }\end{array}$} \\
\hline & & & BS & SM & SP & BM & SA & EC & $\mathrm{PF}$ & $\mathrm{CT}$ & CG & $\mathrm{CA}$ & AS & FG \\
\hline RIC. C. 4 B IV & $\begin{array}{l}\text { Cephalosporium } \\
\text { spp. }\end{array}$ & B & $11 \pm 0.57$ & NA & NA & $14 \pm 0.57$ & $14 \pm 0.03$ & $16 \pm 0.33$ & $12 \pm 0.33$ & NA & NA & NA & NA & NA \\
\hline RIC. C. 1 L III & Rhizopus spp. & $\mathrm{L}$ & NA & NA & NA & $32 \pm 0.66$ & NA & NA & NA & NA & NA & NA & NA & NA \\
\hline RIC. C. 4 L I & Aspergillus spp. & $\mathrm{L}$ & NA & NA & NA & $30 \pm 0.57$ & NA & $20 \pm 0.33$ & NA & NA & NA & NA & NA & NA \\
\hline RIC. C. 5 S I & Aspergillus spp. & $\mathrm{S}$ & NA & NA & NA & $28 \pm 0.03$ & NA & $13 \pm 0.33$ & NA & NA & NA & NA & NA & NA \\
\hline RIC. C. 4 B I a & $\begin{array}{l}\text { Cephalosporium } \\
\text { spp. }\end{array}$ & B & NA & NA & NA & NA & NA & $19 \pm 0.33$ & NA & NA & NA & NA & NA & NA \\
\hline RIC. C. 4 B I b & Aspergillus spp. & B & NA & NA & NA & NA & NA & $12 \pm 0.33$ & NA & NA & NA & NA & NA & NA \\
\hline RIC. C. 1 L III & Penicillium spp. & $\mathrm{L}$ & NA & $14 \pm 0.23$ & NA & NA & NA & $21 \pm 0.57$ & NA & NA & NA & NA & NA & NA \\
\hline RIC. C. 4 B VI & Penicillium spp. & B & NA & NA & NA & NA & NA & $19 \pm 0.33$ & NA & NA & NA & NA & NA & NA \\
\hline RIC. C. 4 B II b & Gliocladium spp. & B & NA & NA & NA & NA & 13 & $20 \pm 0.57$ & NA & NA & NA & NA & NA & NA \\
\hline RIC. C. 4 B II a & Penicillium spp. & B & NA & NA & NA & NA & 15 & $20 \pm 1.20$ & NA & NA & NA & NA & NA & NA \\
\hline RIC. C. $3 \mathrm{~S}$ & $\begin{array}{l}\text { Cephalosporium } \\
\text { spp. }\end{array}$ & $\mathrm{S}$ & NA & NA & NA & NA & NA & NA & NA & NA & NA & NA & NA & NA \\
\hline RIC. C. 4 L II & Penicillium spp. & $\mathrm{L}$ & NA & NA & NA & NA & NA & $18 \pm 0.57$ & NA & NA & NA & NA & NA & NA \\
\hline RIC. C. 5 S II & Penicillium spp. & S & NA & NA & NA & NA & NA & $20 \pm 0.33$ & NA & NA & NA & NA & NA & NA \\
\hline RIC. C. 1 L 1 & Aspergillus spp. & $\mathrm{L}$ & $13 \pm 0.57$ & NA & NA & NA & $12 \pm 0.33$ & NA & NA & NA & $12 \pm 0.33$ & NA & NA & NA \\
\hline RIC. C. 5 LT II & Aspergillus spp. & $\mathrm{L}$ & NA & NA & NA & NA & NA & NA & NA & NA & NA & NA & NA & NA \\
\hline RIC. C. 4 B V & Aspergillus spp. & B & NA & NA & NA & NA & NA & $22 \pm 0.33$ & 12 & NA & NA & NA & NA & NA \\
\hline $\begin{array}{l}\text { RIC. C. } 5 \text { LT \& } \\
\text { B II }\end{array}$ & Penicillium spp. & $\mathrm{L}$ & NA & $22 \pm 0.57$ & $14 \pm 0.03$ & NA & NA & $20 \pm 0.33$ & NA & NA & $22 \pm 0.57$ & NA & NA & NA \\
\hline $\begin{array}{l}\text { RIC. C. } 5 \text { LT \& } \\
\text { B I }\end{array}$ & Aspergillus spp. & $\mathrm{L}$ & NA & NA & NA & NA & NA & NA & NA & $11 \pm 0.57$ & NA & 20 & NA & NA \\
\hline $\begin{array}{l}\text { RIC. C. } 4 \text { LT \& } \\
\text { B V }\end{array}$ & Penicillium spp. & $\mathrm{L}$ & $11 \pm 0.33$ & NA & $12 \pm 0.89$ & NA & NA & $18 \pm 0.57$ & $12 \pm 0.33$ & $13 \pm 0.57$ & NA & $18 \pm 0.79$ & $20 \pm 0.57$ & NA \\
\hline $\begin{array}{l}\text { RIC. C. } 4 \text { LT \& } \\
\text { B III }\end{array}$ & Penicillium spp. & $\mathrm{L}$ & NA & NA & NA & NA & NA & NA & $18 \pm 0.57$ & $11 \pm 0.33$ & $13 \pm 0.57$ & 14 & NA & NA \\
\hline
\end{tabular}




\begin{tabular}{|c|c|c|c|c|c|c|c|c|c|c|c|c|c|c|}
\hline $\begin{array}{l}\text { RIC. C. } 4 \text { L \& S } \\
\text { II }\end{array}$ & Aspergillus spp. & $\mathrm{L}$ & NA & $13 \pm 0.33$ & NA & $17 \pm 0.51$ & $16 \pm 0.66$ & $17 \pm 0.57$ & NA & NA & NA & NA & NA & NA \\
\hline $\begin{array}{l}\text { RIC. C. } 4 \text { L \& S } \\
\text { I }\end{array}$ & Penicillium spp. & $\mathrm{L}$ & NA & NA & NA & NA & $12 \pm 0.57$ & NA & NA & NA & $20 \pm 0.57$ & NA & $17 \pm 0.51$ & NA \\
\hline $\begin{array}{l}\text { RIC. C. } 4 \text { LT \& } \\
\text { B IV }\end{array}$ & Aspergillus spp. & B & NA & NA & NA & NA & NA & $17 \pm 0.57$ & NA & NA & $12 \pm 0.33$ & NA & $20 \pm 0.57$ & NA \\
\hline $\begin{array}{l}\text { RIC. C. } 4 \text { LT \& } \\
\text { B II }\end{array}$ & Aspergillus spp. & B & NA & NA & NA & NA & NA & NA & NA & NA & NA & NA & $23 \pm 0.57$ & NA \\
\hline $\begin{array}{l}\text { RIC. C. } 4 \text { LT \& } \\
\text { B I }\end{array}$ & Aspergillus spp. & B & NA & NA & NA & NA & NA & $27 \pm 0.57$ & $32 \pm 0.57$ & NA & NA & NA & $24 \pm 0.33$ & $36 \pm 0.57$ \\
\hline RIC. C. 3 S VII & Penicillium spp. & $\mathrm{S}$ & NA & $12 \pm 0.57$ & $11 \pm 0.33$ & NA & $16 \pm 1.15$ & $22 \pm 0.57$ & $16 \pm 0.66$ & $21 \pm 0.57$ & NA & $15 \pm 0.88$ & NA & NA \\
\hline RIC. C. 3 S IV & Aspergillus spp. & $\mathrm{S}$ & NA & $12 \pm 0.57$ & $13 \pm 0.57$ & NA & $18 \pm 0.57$ & $24 \pm 0.57$ & 16 & $13 \pm 0.33$ & $12 \pm 0.89$ & $15 \pm 0.51$ & NA & NA \\
\hline RIC. C. 3 S V & Penicillium spp. & $\mathrm{S}$ & NA & NA & NA & NA & $16 \pm 0.66$ & $20 \pm 1.20$ & $15 \pm 0.66$ & $21 \pm 0.57$ & NA & $12 \pm 0.33$ & NA & NA \\
\hline RIC. C. 3 S VIII & Penicillium spp. & $\mathrm{S}$ & NA & NA & $11 \pm 0.33$ & NA & NA & NA & $15 \pm 0.33$ & $20 \pm 0.33$ & NA & $15 \pm 0.33$ & NA & NA \\
\hline RIC. C. 3 S IV & Aspergillus spp. & $S$ & $13 \pm 0.88$ & NA & $13 \pm 0.79$ & NA & NA & $20 \pm 0.33$ & NA & NA & NA & $14 \pm 0.66$ & NA & NA \\
\hline RIC. C. 3 S I & Aspergillus spp. & $\mathrm{S}$ & $15 \pm 0.66$ & NA & $17 \pm 0.57$ & NA & NA & $21 \pm 0.57$ & NA & NA & NA & $23 \pm 0.33$ & NA & NA \\
\hline RIC. C. 3 S II & Penicillium spp. & $\mathrm{S}$ & $17 \pm 0.51$ & NA & $21 \pm 0.33$ & NA & NA & $24 \pm 0.57$ & NA & $23 \pm 0.57$ & $23 \pm 0.33$ & $30 \pm 0.57$ & NA & NA \\
\hline RIC. C. 3 S III & Aspergillus spp. & $S$ & $15 \pm 0.66$ & NA & $17 \pm 0.51$ & NA & NA & $29 \pm 0.57$ & NA & NA & NA & $26 \pm 0.57$ & NA & NA \\
\hline $\begin{array}{l}\text { POSITIVE } \\
\text { CONTROL }\end{array}$ & & & $48 \pm 0.57$ & $35 \pm 0.33$ & 0 & $39 \pm 0.33$ & $38 \pm 0.57$ & $40 \pm 0.57$ & $50 \pm 0.57$ & 0 & 0 & 0 & 0 & 0 \\
\hline
\end{tabular}

Values are mean inhibition zone $(\mathrm{mm}) \pm$ S.D of three replicates

Legend:NA: no antimicrobial activity; negative control: Dimethyl Sulphoxide; positive control: Ciprofloxacin as antibacterial agent (1mg.ml-1); Fluconazol as antifungal agent(1mg.ml-1); B: Bean; L: Leaf; S: Stem; SM: Streptococcus mutans (MTCC 497); SA: Staphylococcus aureus (MTCC 7443); SP: Streptococcus pyogenes (MTCC 1924); BM: Bacillus megaterim (MTCC 428); BS: Bacillus subtilis (MTCC 121); EC: Escherichia coli (MTCC 40); PS: Pseudomonas fluorescens (MTCC 1748); CA: Candida albicans (MTCC 227); CG: Candida glabrata (MTCC 3814); CT: Candida tropicalis (MTCC 3421 ); AS: Alternaria solani (MTCC 10690); FG: Fusarium graminearum (MTCC 2089).

Thus, the results in the Table 1 makes it evident that the potential of endophytic fungi in producing the antimicrobial secondary metabolites against both prokaryotic and eukaryotic pathogens.

An inhibition zone of $36 \pm 0.57 \mathrm{~mm}$. (in diameter) against $F$. graminearum was the maximum zone of inhibition obtained in the present study. The zone was shown by fungi isolated from the bark of castor plant. The minimum zone of inhibition of endophytic fungi isolated from the bark of castor plant was observed to be $11 \pm 0.33 \mathrm{~mm}$. (in diameter) against $B$. subtilis. While the funga metabolites from the stem of endophytic fungi of castor plant displayed the maximum inhibition zone of $30 \pm 0.57 \mathrm{~mm}$. (in diameter) against candida albicans, the minimum inhibition zone reported was $11 \pm 0.33 \mathrm{~mm}$. (in diameter) against $S$. pyogenes. One of the leaf isolate did not showed antimicrobial activity against any of the twelve test pathogens. However, among the rest of the fungal endophytes isolated from the leaf of castor plant, the maximum zone of inhibition observed was of $32 \pm 0.66 \mathrm{~mm}$. (in diameter) against $B$. megaterim and minimum zone being $11 \pm 0.33 \mathrm{~mm}$.(in diameter) against $C$. tropicalis and $B$. subtilis. Almost all the isolates, except one, showed activity against at least one of the pathogenic microorganisms. $15 \%$ endophytic fungal isolates showed antimicrobial activity against $A$. solani and B. megaterim, $21 \%$ against $B$. subtilis and $C$. glabrata, $33 \%$ against $C$. tropicalis and C. albicans, $72 \%$ against $E$. coli, $3 \%$ against $F$. graminearum, $27 \%$ against $P$. fluorescens, $S$. aureus and $S$. pyogenes and $15 \%$ fungal isolates were antagonistic to $S$. mutans (Figure1). Endophytic fungi isolated from the Ricinus communis were identified based on the analysis of spore structure, pigment formation and colony morphology (Table 1). Highly diverse endophytic fungal isolates were obtained. The endophytic fungi belonging to Cephalosporium, Aspergillus, Penicillium, Rhizopus and Gliocladium spp. were obtained. Majority of the endophytic fungal isolates obtained from the different parts of the castor plant were identified as Aspergillus spp. and Penicillium spp.

Table 3 The relative colonization frequency (\%CF) and Dominance of endophytic fungi

\begin{tabular}{lccc}
\hline $\begin{array}{l}\text { ENDOPHYTIC } \\
\text { FUNGI }\end{array}$ & $\begin{array}{c}\text { TOTAL } \\
\text { ISOLATES } \\
\text { OF EACH } \\
\text { FUNGUS }\end{array}$ & $\begin{array}{c}\text { RELATIVE } \\
\text { COLONIZATION } \\
\text { FREQUENCY } \\
(\% \text { CF })\end{array}$ & $\begin{array}{c}\text { DOMINANCE } \\
\text { OF FUNGI }\end{array}$ \\
\hline $\begin{array}{l}\text { Cephalosporium } \\
\text { spp. }\end{array}$ & 03 & 0.83 & 3.21 \\
$\begin{array}{l}\text { Aspergillus spp. } \\
\text { Penicillium spp. }\end{array}$ & 15 & 12.50 & 48.41 \\
\hline $\begin{array}{l}\text { Rhizopus spp. } \\
\text { Gliocladium } \\
\text { spp. }\end{array}$ & 01 & 10.83 & 41.94 \\
$\begin{array}{l}\text { No. of isolates } \\
\text { recovered }\end{array}$ & 01 & 0.83 & 3.21 \\
\hline $\begin{array}{l}\text { Relative colonization frequency }(\% \mathrm{CF}) \text { based on } 120 \text { segments plated. } \\
\end{array}$ & 0.83 & 3.21 \\
\hline
\end{tabular}

Maximum dominance was displayed by Aspergillus spp. (48.41) whereas the Penicillium spp. showed fungal dominance of 41.94. Cephalosporium spp., Rhizopus spp. and Gliocladium spp. displayed dominance value of 3.21. The relative frequency of colonization ranged from 0.83 to $12.50 \%$ (Table 3). The highest value of relative colonization frequency (\%CF) was $25 \%$ for Aspergillus species.

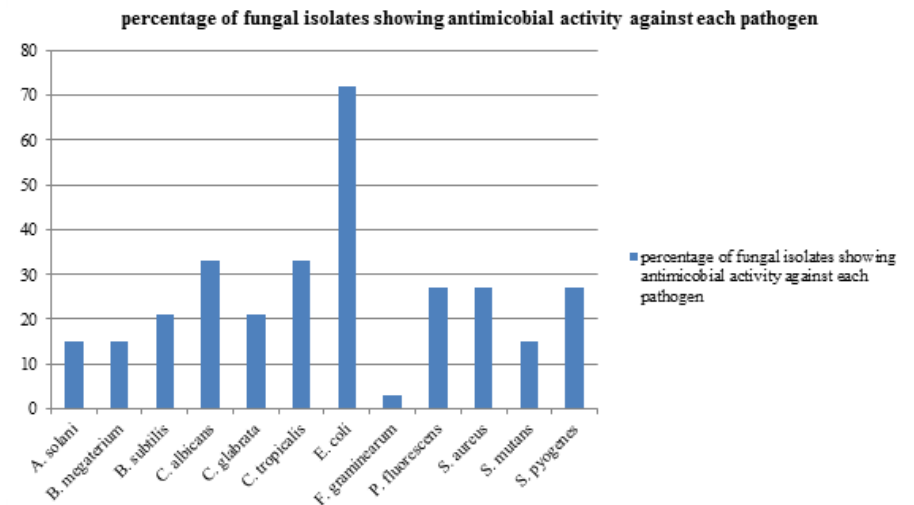

Figure 1 The percentage of fungal isolates showing antimicrobial activity against the test pathogens.

Many past studies have shown that generally, gram positive bacteria are more susceptible towards plants extracts as compared to gram negative bacteria but in the present study we found that crude extracts of endophytic fungi from the Ricinus communis plant had more antagonistic activity against gram negative bacteria then gram positive bacteria. Hence, endophytic fungi from the Ricinus communis plant are a potent source of broad spectrum antimicrobial compounds which can be used to make commercial drugs (Singh et al., 2012).

\section{CONCLUSION}

The crude extracts obtained from the endophytic fungi of Ricinus communis showed a great potential as an effective antimicrobial agent. A further study on these fungal isolates should be performed to establish the safety and efficacy of these fungal extracts as pharmaceutical drugs.

Acknowledgement: The authors are grateful to the Honorable Vice-Chancellor, Kurukshetra University, Kurukshetra and the Director, University Institute of Engineering and Technology, Kurukshetra University, Kurukshetra for providing infrastructure facilities to carry out the research work.

\section{REFERENCES}

AINSWORTH, G.C., SPARROW, F.K., SUSSMAN, A.S. 1973. The Fungi: advanced Treaties, Taxonomic Review with Keys (Vol. IV A). Academic Press, New York, USA. http://dx.doi.org/10.1002/jobm.19740140812

AZHARI, S., PIRDADEH, S., LOTFALIZADEH, M., SHAKERI, M.T. 2006 Evaluation of the effect of castor oil on initiating labor in term pregnancy. Saudi Medical Journal, 27 (7), 1011-4. 
BARNETT, H.L., HUNTER, B.B. 1998. Illustrated Genera of Imperfect Fungi. (4th ed.) Mac Millan Publ. Co. ISBN: 0-89054-192-2, New York. http://dx.doi.org/10.1002/fedr.4911000913

BENSKY, D., CLAVEY, S., STOGER, E., GAMBLE, A. 2004. Chinese Herbal Medicine: Materia Medica, Eastland Press,Third Edition, 1311P, ISBN-13 9780939616428.

CAROL, A., BASCOM-SLACK, MA., C.,MOORE, E., BABBS, B., FENN, K., GREENE, J.S., HANN, B.D., KEEHNER, J., KELLEY-SWIFT, E.G., KEMBAIYAN, V., LEE, S.J., LI, P.D.Y., LIN, E. H., SCHORN, M.A., VEKHTER, D., BOULANGER, L., HESS, W. M., VARGAS, P.N., STROBEL, G.A., STROBEL, S.A. 2009. Multiple, Novel Biologically Active Endophytic Actinomycetes Isolated from Upper Amazonian Rainforests. Microbial Ecology, 58, 374-383. http://dx.doi.org/10.1007/s00248-009-9494-z

CORRADO, M., RODRIGUES, K.F. 2004. Antimicrobial evaluation of fungal extracts produced by endophytic strains of Phomopsis sp.. Journal of Basic Microbiology, 44, 157-160. http://dx.doi.org/10.1002/jobm.200310341

CUTLER, S.J., CUTLER, H.G. 2000. Biologically active natural products: pharmaceuticals. CRC Press. p. 5. ONLINE ISBN 978-94-011-4173-4. http://dx.doi.org/10.1021/np9907329

ELLIS, M.B. 1971. Dematiaceous Hyphomycetes, Commonwealth Mycological Institute, Kew, Surrey England.

ELLIS, M.B. 1976. More Dematiaceous Hyphomycetes, Commonwealth Mycological Institute, Kew, Surrey England.

KOTA, C.S., SARVANI, M. 2011. Antibacterial activity of Ricinus communis leaf extract. International Journal of Pharmaceutical Sciences and Research, 2 (5), 1259-1261.

KUMAR, K., GUPTA, S.C., BAIDOO, S.K., CHANDER, Y., ROSEN, C.J.2005. Antibiotic Uptake by Plants from Soil Fertilized with Animal Manure. Journal of Environmental Quality, 34 (6), 2082-2085. http://dx.doi.org/10.2134/jeq2005.0026

KUMAR, K.A., RAI, .K.M.L., UMESHA, K.B. 2002. Evaluation of antibacterial activity of 3,5-dicyano-4,6-diaryl-4-ethoxycarbonyl-piperid-2-ones. Journal of Pharmaceutical and Biomedical Analysis, 27(5), 837-840. http://dx.doi.org/10.1016/s0731-7085(01)00456-3

MATHUR, A., VERMA,S.K., YOUSUF, S., SINGH, S.K., PRASAD, G.B.K.S., DUA, V.K. 2011. Antimicrobial potential of roots of Riccinus communis against pathogenic microorganisms. International Journal of Pharma and Bio Sciences, 2 (1), 545-548.

MOMOH, A.O., OLADUNMOYE, M.K., ADEBOLU,T.T. 2012.Evaluation of the Antimicrobial and Phytochemical Properties of Oil from Castor Seeds (Ricinus communis Linn), Bulletin of Environment, Pharmacology and Life Sciences, 1 (10), 21-27.

NAZ, R., BANO, A. 2012. Antimicrobial potential of Ricinus communis leaf extracts in different solvents against pathogenic bacterial and fungal strains. Asian journal of tropical biomedicine, 2 (12), 944-947. http://dx.doi.org/10.1016/s2221-1691(13)60004-0

NEWMAN, D.J., CRAGG, G.M. 2007. Natural products as sources of new drugs over the last 25 years. Journal of Natural Products, 70, 461-477. http://dx.doi.org/10.1021/np068054v

PETRINI, O., SIEBER, T.N., TOTI, L., VIRET O. 1992. Ecology, metabolite production, and substrate utilization in endophytic fungi. Natural Toxins, 1, 185196. http://dx.doi.org/10.1002/nt.2620010306

RADJI, M., SUMIATI, A., RACHMAYANI, R., ELYA, B. 2011. Isolation of fungal endophytes from Garcinia mangostana and their antibacterial activity. African Journal of Biotechnology, 10 (1), 103-107.

RANA, M., DHAMIJA, H., PRASHAR, B., SHARMA, S. 2012. Ricinus communis L.- A Review. Internatonal Journal Of Pharm Tech Research, 4 (4), 1706-1711.

SINGH, S.K., VISHNOI, R.,DHINGRA, G.K., KISHOR,K. 2012. Antibacterial activity of leaf extracts of some selected traditional medicinal plants of Uttarakhand, North East India. Journal of Applied and Natural Science, 4 (1), $47-$ 50.

SINGH, S.K., STROBEL, G. A., KNIGHTON, B., GEARY, B., SEARS, J., EZRA, D. 2011. An Endophytic Phomopsis sp. Possessing Bioactivity and Fuel Potential with its Volatile Organic Compounds. Microbial Ecology , 61, 729739. http://dx.doi.org/10.1007/s00248-011-9818-7

STROBEL, G., DAISY, B. 2003. Bioprospecting for microbial endophytes and their natural products. Microbiology Molecular Biology Reviews, 67, 491-502. http://dx.doi.org/10.1128/mmbr.67.4.491-502.2003

SURYANARAYANAN, T.S. 1992. Light incubation: a neglected procedure in mycology. Mycologist, 6, 144. http://dx.doi.org/10.1016/s0269-915x(09)806034

TAYUNG, K., JHA, D. K.2010. Antimicrobial endophytic fungal assemblages inhabiting bark of Taxus baccata L. of Indo-Burma mega biodiversity hotspot. Indian journal of Microbiology, 50 (1), S74-S81. http://dx.doi.org/10.1007/s12088-010-0056-3

ZAHNER, H., DRAUTZ, H., WEBER, W. 1982. Novel approaches to metabolite screening, in Bioactive Secondary Metabolites, Search and Discovery (Bu'Lock, J. D., Nisbet, L. J., Winstanley, D J , eds.), Academic 